\title{
Pengembangan Metode Peningkatan Kualitas Laporan Keuangan pada PT Pelabuhan Indonesia IV Berbasis Good Corporate Governance di Kota Parepare
}

\author{
Darmawan $^{1}$, Djamal Abdi ${ }^{2}$
}

${ }^{1,2}$ Universitas Muhammadiyah Parepare

\section{INFO NASKAH}

Diserahkan

25 Juli 2017

Diterima

30 Juli 2017

Diterima dalam revisi

18 Desember 2017

Diterima dan disetujui

19 Desember 2017

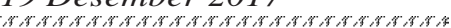

\section{Kata Kunci:}

Laporan keuangan

Good Corporate Governance

\begin{abstract}
ABSTRAK
Penelitian ini bertujuan un good corporate governance terhadap kualitas laporan keuangan di PT Pelabuhan Indonesia IV. Desain penelitian ini menggunakan metode deskriptif analitis dengan pendekatan studi kasus. Teknik pengambilan sampel menggunakan total sampling dengan jumlah sampel 20 karyawan PT Pelabuhan Indonesia IV. Pengumpulan data menggunakan kuisioner yang diberikan kepada responden. Analisis statistik yang digunakan dalam penelitian ini adalah menggunakan analisis statistik regresi linier. Hasil penelitian menerangkan bahwa mayoritas karyawan setuju dengan penerapan prinsip GCG yaitu masing-masing 50\% untuk variabel transparansi, 50\% untuk variabel akuntabilitas, dan $65 \%$ untuk variabel responsibility serta 50\% untuk kualitas laporan keuangan dan untuk semua variabel tidak ada $(0 \%)$ yang mengatakan tidak setuju maupun sangat tidak setuju. Selain itu, prinsip good corporate governance berpengaruh terhadap kualitas laporan keuangan.
\end{abstract}

\section{Pendahuluan}

Beberapa perusahaan besar di Indonesia ada yang bermasalah dan bahkan tidak mampu lagi meneruskan kegiatan usahanya akibat menjalankan praktik tata kelola perusahaan yang buruk (bad corporate governance). Akibat berbagai praktek tata kelola perusahaan yang buruk oleh perusahaan besar ini bukan saja telah menimbulkan krisis ekonomi di Indonesia tetapi juga mempengaruhi perekonomian di AS dan dunia. Penerapan dan pengelolaan corporate governance yang baik menekankan konsep pentingnya pemegang saham untuk memperoleh informasi dengan benar, akurat, dan tepat waktu. Era persaingan global saat ini, yang batasbatas negara tidak lagi menjadi penghalang untuk berkompetisi, hanya perusahaan yang menerapkan good corporate governance (GCG) yang mampu memenangkan persaingan. 
Good corporate governance (GCG) adalah salah satu elemen kunci dalam meningkatkan efisiensi ekonomis, yang meliputi serangkaian hubungan antara manajemen perusahaan, dewan komisaris, para pemegang saham, dan stakeholder lainnya. GCG merupakan suatu keharusan dalam rangka membangun kondisi perusahaan yang tangguh dan sustainable serta sangat diperlukan untuk menciptakan sistem dan pengelolaan keuangan perusahaan yang kuat sehingga mampu menjadi perusahaan yang kompetitif.

Tuntutan penerapan GCG juga dirasakan oleh seluruh perusahan di Indonesia. Tuntutan tersebut dimaksudkan agar perusahaan-perusahaan yang ada di Indonesia tidak tertekan oleh perusahaan-perusahaan asing dan persaingan global yang semakin berat. Badan Usaha Milik Negara (BUMN) sebagai perusahaan penyumbang terbesar dalam perkembangan pembangunan di Indonesia, tidak luput bahkan sering menjadi sorotan dari masyarakat maupun media dan mendapat berbagai bentuk kritikan atas kinerja perusahaan BUMN selama ini.

PT Pelabuhan Indonesia IV (Persero) merupakan salah satu perusahaan BUMN yang bergerak pada penyedia layanan jasa kepelabuhan di Indonesia. Mendapatkan keuntungan merupakan tujuan utama dari setiap perusahaan termasuk PT Pelabuhan Indonesia, dan hal tersebut tidak akan lepas dari masalah-masalah yang akan datang dan menghalangi perusahaan dalam mencapai tujuan mereka. Salah satu masalah yang mungkin akan dialami perusahaan adalah buruknya pengelolaan di dalam perusahaan dan tidak berfungsinya sistem perencanaan dan pengendalian internal yang mengakibatkan perusahaan mengalami kerugian.

Salah satu upaya yang dilakukan PT Pelabuhan Indonesia (Pelindo) IV (Persero) dalam pengendalian gratifikasi adalah melakukan kerjasama dengan Komisi Pemberantasan Korupsi (KPK). Hal tersebut dilakukan dalam rangka mewujudkan komitmen sebagai Badan Usaha Milik Negara (BUMN) yang selalu patuh dan menerapkan prinsip tata kelola perusahaan yang baik (good corporate governance) serta dalam rangka pengendalian gratifikasi guna mendukung upaya pemberantasan tindak pidana korupsi di lingkungan PT Pelabuhan Indonesia (Pelindo) IV (Persero) Cabang Parepare.

Good corporate governance (GCG) yaitu prinsip yang mendasari suatu proses dan mekanisme pengelolaan perusahaan berlandaskan peraturan perundang-undangan dan etika berusaha (Kepmen BUMN, Kep-100/MBU/2002). Corporate governance merupakan suatu sistem yang mengatur hubungan antara dewan komisaris, direksi, dan manajemen agar tercipta keseimbangan dalam pengelolaan perusahaan. Perusahaan yang telah menerapkan corporate governance dengan baik seharusnya sudah memenuhi prinsip-prinsip GCG yaitu fairness, 
transparency, accountability, dan responsibility. Keempat komponen tersebut penting karena penerapan prinsip- prinsip GCG tersebut secara konsisten terbukti dapat meningkatkan kualitas laporan keuangan (Arief dan Bambang dalam Sapitri 2010).

Laporan keuangan yang berkualitas harus mampu menyediakan informasi yang relevan dan berguna dalam pengambilan keputusan ekonomi maupun keputusan investasi bagi para penggunanya. Informasi dalam laporan keuangan juga harus memiliki kriteria andal (reliable). Menurut Ikatan Akuntan Indonesia (2004), informasi dapat dikategorikan andal apabila bebas dari pengertian yang menyesatkan, adanya kesalahan material, dan dapat diandalkan oleh pengguna laporan keuangan sebagai penyajian yang tulus atau jujur dari yang seharusnya disajikan atau yang secara wajar diharapkan dapat disajikan sehingga dapat mengurangi munculnya manipulasi akuntansi.

Skandal manipulasi melibatkan beberapa perusahaan besar yang dahulunya mempunyai kualitas audit yang tinggi di Amerika seperti Enron, Tyco, Global Crossing, dan Worldcom (Susiana dan Herawaty dalam Oktadella 2011). Beberapa kasus yang terjadi di Indonesia, seperti PT Lippo Tbk dan PT Kimia Farma Tbk juga melibatkan pelaporan keuangan (financial reporting) yang berawal dari terdeteksi adanya manipulasi (Gideon dalam Oktadella 2011). Kasus manipulasi tersebut terbukti bahwa adanya keterlibatan pihak-pihak dalam, seperti chief executive officer (CEO), komisaris, internal auditor, dalam melakukan kecurangan akuntansi. Hal ini menurunkan kepercayaan masyarakat terhadap kinerja perusahaan ditandai dengan turunnya harga saham perusahaan (Susiana dan Herawaty dalam Oktadella 2011).

Berdasarkan hal tersebut di atas, peneliti tertarik untuk melakukan penelitian tentang "pengembangan metode peningkatan laporan keuangan pada PT Pelabuhan Indonesia IV berbasis good corporate governance di Kota Parepare".

\section{Metode Penelitian}

\subsection{Pendekatan Penelitian}

Penelitian ini menggunakan metode deskriptif analitis dengan pendekatan studi kasus. Penggunaan metode ini dilakukan untuk melihat dan menggambarkan lingkungan dengan keadaan nyata yang tampak dalam perusahaan dengan cara mengumpulkan, menyajikan, dan menganalisis data sehingga dapat memberikan gambaran yang cukup jelas mengenai objek yang diteliti. Penelitian ini dilaksanakan di PT Pelabuhan Indonesia IV Kota Parepare pada tahun 2017. Populasi dan sampel dalam penelitian ini sebanyak 20 sampel yang terdiri dari seluruh 
pegawai pada PT Pelabuhan Indonesia IV Cabang Parepare. Instrumen yang digunakan pada penelitian ini adalah kuesioner dan alat tulis menulis. Pengumpulan data dilakukan dengan cara observasi dan dokumentasi.

\subsection{Variabel Penelitian}

Penelitian ini terdiri dari satu variabel dependen (kualitas laporan keuangan) dan tiga variabel independen meliputi transparansi, akuntabilitas, dan responsibility.

\subsection{Metode Analisis Data}

Metode Analisis data yang digunakan dalam penelitian ini adalah analisis statistik dengan bantuan Program SPSS.

\section{Hasil dan Pembahasan}

\subsection{Hasil}

\section{Karakteristik Responden}

Karakteristik umum dalam penelitian ini mencakup jenis kelamin, kelompok umur, dan pendidikan.

Tabel 1. Sebaran Berdasarkan Jenis Kelamin, Kelompok Umur, Pendidikan

\begin{tabular}{lcc}
\hline \multicolumn{1}{c}{ Karakteristik } & n & Persentase \\
\hline Jenis Kelamin & & \\
1. Laki-laki & 11 & $55,0 \%$ \\
2. Perempuan & 9 & $45,0 \%$ \\
\hline Kelompok Umur (Tahun) & & \\
$1 . \quad 30$ & 3 & $15,0 \%$ \\
$2 . \quad 31-40$ & 8 & $40,0 \%$ \\
3. $41-50$ & 5 & $25,0 \%$ \\
4. $\quad 51$ & 4 & $20,0 \%$ \\
\hline Pendidikan Terakhir & & \\
1. SMA & 5 & $25,0 \%$ \\
2. D3 & 1 & $5,0 \%$ \\
3. S1 & 13 & $65,0 \%$ \\
4. S2 & 1 & $5,0 \%$ \\
\hline Sumber: Data primer 2017 & &
\end{tabular}

Sebaran berdasarkan jenis kelamin, kelompok umur, dan pendidikan dapat dilihat pada tabel 1 yang menunjukkan bahwa mayoritas karyawan PT Pelabuhan Indonesia IV Cabang Parepare berjenis kelamin laki-laki (55\%), dan kelompok umur mayoritas berumur 31-40 tahun (40\%). Tingkat pendidikan karyawan pada PT Pelabuhan Indonesia IV Cabang Parepare adalah 
mayoritas starata satu (65\%). Melihat sumber daya manusia yang dimiliki oleh PT Pelabuhan Indonesia IV Cabang Parepare memberikan sebuah indikasi dan jaminan bahwa perusahaan tersebut dapat dikelola secara profesional dan sesuai prinsip good corporate governance.

\section{Karakteristik Variabel}

Tabel 2. Penerapan Prinsip Transparansi

\begin{tabular}{|l|c|c|}
\hline \multicolumn{1}{|c|}{ Kriteria } & n & Persentase \\
\hline Sangat Setuju & 7 & $35,0 \%$ \\
Setuju & 10 & $50,0 \%$ \\
Kurang Setuju & 3 & $15,0 \%$ \\
Tidak Setuju & 0 & $0,0 \%$ \\
Sangat Tidak Setuju & 0 & $0,0 \%$ \\
\hline TOTAL & 20 & $100 \%$ \\
\hline
\end{tabular}

Sumber: Data primer 2017

Data pada tabel 2 menunjukkan bahwa pengelolaan keuangan pada PT Pelabuhan Indonesia IV Cabang Parepare sudah dikelola secara profesional dan sesuai dengan prinsip good corporate governance yaitu prinsip transparansi. Hal ini dibuktikan dengan hasil penelitian yang menunjukkan bahwa sebanyak 50\% karyawan menyatakan setuju terhadap pernyataan bahwa PT Pelabuhan Indonesia IV Cabang Parepare sudah menerapkan prinsip transparansi dalam pengelolaan keuangan perusahaan.

Tabel 3. Penerapan Prinsip Akuntabilitas

\begin{tabular}{|l|c|c|}
\hline \multicolumn{1}{|c|}{ Kriteria } & Responden & Persentase \\
\hline Sangat Setuju & 6 & $30,0 \%$ \\
Setuju & 10 & $50,0 \%$ \\
Kurang Setuju & 4 & $20,0 \%$ \\
Tidak Setuju & 0 & $0,0 \%$ \\
Sangat Tidak Setuju & 0 & $0,0 \%$ \\
\hline TOTAL & 20 & $100 \%$ \\
\hline
\end{tabular}

Sumber: Data primer 2017

Data pada tabel 3 menunjukkan bahwa pengelolaan keuangan pada PT Pelabuhan Indonesia IV Cabang Parepare sudah dikelola secara profesional dan sesuai dengan prinsip good corporate governance yaitu prinsip akuntabilitas. Hal ini dibuktikan dengan hasil penelitian yang menunjukkan bahwa sebanyak 50\% karyawan menyatakan setuju terhadap pernyataan bahwa PT Pelabuhan Indonesia IV Cabang Parepare sudah menerapkan prinsip akuntabilitas dalam pengelolaan keuangan perusahaan. 
Tabel 4. Penerapan Prinsip Responsibility

\begin{tabular}{|l|c|c|}
\hline \multicolumn{1}{|c|}{ Kriteria } & Responden & Persentase \\
\hline Sangat Setuju & 4 & $15,0 \%$ \\
Setuju & 13 & $65,0 \%$ \\
Kurang Setuju & 3 & $20,0 \%$ \\
Tidak Setuju & 0 & $0,0 \%$ \\
Sangat Tidak Setuju & 0 & $0,0 \%$ \\
\hline TOTAL & 20 & $100 \%$ \\
\hline
\end{tabular}

Sumber: Data primer 2017

Data pada tabel 4 menunjukkan bahwa pengelolaan keuangan pada PT Pelabuhan Indonesia IV Cabang Parepare sudah dikelola secara profesional dan sesuai dengan prinsip good corporate governance yaitu prinsip respontability. Hal ini dibuktikan dengan hasil penelitian yang menunjukkan bahwa sebanyak $65 \%$ karyawan menyatakan setuju terhadap pernyataan bahwa PT Pelabuhan Indonesia IV Cabang Parepare sudah menerapkan prinsip respontability dalam pengelolaan keuangan perusahaan.

Tabel 5. Kualitas Laporan Keuangan

\begin{tabular}{|l|c|c|}
\hline \multicolumn{1}{|c|}{ Kriteria } & Responden & Persentase \\
\hline Sangat Setuju & 9 & $45,0 \%$ \\
Setuju & 10 & $50,0 \%$ \\
Kurang Setuju & 1 & $5,0 \%$ \\
Tidak Setuju & 0 & $0,0 \%$ \\
Sangat Tidak Setuju & 0 & $0,0 \%$ \\
\hline TOTAL & 20 & $100 \%$ \\
\hline
\end{tabular}

Sumber: Data primer 2017

Data pada tabel 5 menunjukkan bahwa PT Pelabuhan Indonesia IV Cabang Parepare telah menyusun laporan keuangan yang sesuai dengan standar khususnya standar akuntansi. Hal ini dibuktikan dengan hasil penelitian yang menunjukkan bahwa sebanyak 50\% karyawan menyatakan setuju terhadap pernyataan bahwa PT Pelabuhan Indonesia IV Cabang Parepare memiliki laporan keuangan yang berkualitas.

\section{Pengujian Hipotesis}

Hipotesis penelitian dalam penelitian ini diuji dengan analisis regresi berganda. Hasil pengujian hipotesis dalam penelitian ini terlihat dalam tabel berikut ini: 
Tabel 6. Hasil Pengujian Hipotesis

\begin{tabular}{|c|c|c|c|c|c|}
\hline \multirow{2}{*}{ Variabel } & \multirow{2}{*}{ Prediksi } & $\begin{array}{c}\text { Jumlah } \\
\text { Responden }\end{array}$ & \multicolumn{2}{|c|}{ Model } & \multirow{2}{*}{ Kesimpulan } \\
\cline { 4 - 5 } & & & Kualitas Laporan Keuangan) & \\
\hline Konstanta & & & 0,272 & 0,69 & \\
\hline Transaparansi & + & 312 & 0,333 & 0,02 & Terdukung \\
\hline Akuntabilitas & + & 312 & 0,278 & 0,04 & Terdukung \\
\hline Responsibility & + & 312 & 0,404 & 0,01 & Terdukung \\
\hline
\end{tabular}

\subsection{Pembahasan}

\section{Pengaruh Transparansi terhadap Kualitas Laporan Keuangan}

Transparansi dalam penelitian ini berpengaruh signifikan terhadap kualitas laporan keuangan (H1 terdukung). Hasil ini sejalan dengan temuan sebelumnya (Sugiarto, 2011; Baidaie, 2013). Hasil analisis jawaban responden juga mendukung bahwa variabel transparansi sudah dilaksanakan dengan baik oleh PT Pelabuhan Indonesia IV (Persero) Parepare. Artinya, ketika variabel transparansi yang dilakukan semakin baik, maka kualitas laporan keuangan PT Pelabuhan Indonesia IV (Persero) Parepare juga akan semakin baik. Sehingga untuk meningkatkan kualitas laporan keuangan perlu dilakukan transparansi pada perusahaan. Perusahaan harus menyediakan informasi yang cukup, akurat, dan tepat waktu kepada pihak yang berkepentingan dengan perusahaan tersebut. Selain itu, para investor harus dapat mengakses informasi penting perusahaan secara mudah pada saat diperlukan.

\section{Pengaruh Akuntabilitas terhadap Kualitas Laporan Keuangan}

Akuntabilitas dalam penelitian ini berpengaruh signifikan terhadap kualitas laporan keuangan (H2 terdukung). Hasil ini sejalan dengan temuan sebelumnya (Sugiarto, 2011; Baidaie, 2013). Analisis responden juga mendukung bahwa variabel akuntabilitas PT Pelabuhan Indonesia IV (Persero) Parepare berjalan dengan baik. Artinya, perusahaan memiliki akuntabilitas yang baik, maka kualitas laporan keuangan juga akan semakin baik.

\section{Pengaruh Responsibility terhadap Kualitas Laporan Keuangan}

Responsibility dalam penelitian ini berpengaruh signifikan terhadap kualitas laporan keuangan (H3 terdukung). Hasil ini sejalan dengan temuan sebelumnya (Achmad, 2015). Hal ini mengindikasikan untuk meningkatkan kualitas laporan keuangan, perlu dilakukan peningkatan responsibility. Analisis responden juga mendukung bahwa responsibility PT. Pelabuhan Indonesia IV (Persero) Parepare berjalan dengan baik. Hal ini membuktikan bahwa, 
suatu perusahaan dapat bertahan dan berkesinambungan apabila dikelola secara profesional khususnya dalam pengelolaan laporan keuangan.

\section{Simpulan dan Saran}

Berdasarkan hasil penelitian yang dilakukan, maka beberapa kesimpulan dalam penelitian ini adalah mayoritas karyawan setuju dengan penerapan prinsip GCG; prinsip good corporate governance berpengaruh terhadap kualitas laporan keuangan pada PT Pelabuhan Indonesia IV Cabang Parepare. Diharapkan bagi general manager agar senantiasa konsisten dalam menjalankan pripsip good corporate governance dalam menjalankan manajemen perusahaan khususnya dalam pengelolaan keuangan dan bagi karyawan agar senantiasa mendukung penerapan prinsip good corporate governance yang dilakukan oleh general manager khususnya pada PT Pelabuhan Indonesia IV (Persero) Cabang Parepare.

\section{Daftar Pustaka}

Arifani, R. 2011. Pengaruh Good Corporate Governance Terhadap Kinerja Keuangan Perusahaan. Jurnal Ekonomi ECONOMOS, 4 (6): 25-38.

Arsyiati, Darwanis, dan Djalil. 2008, Pengaruh Kualitas SDM Dalam Pengelolaam Keuangan Terhadap Kualitas Pertanggungjawaban Keuangan PNPB dalam Upaya Meningkatkan Kinerja Instansi pada Univ. Syiah Kuala. Jurnal Telaah \& Riset Akuntansi, 1 (1): 29-49.

http://bppt.Jabarprov.go.id/assest/data/arsip/UU-9-BUMN.PDF. Diakses tanggal 12 Desember 2016.

Ferial, F., Suhadak, dan Handayani. 2016. Pengaruh GCG terhadap Kinerja Keuangan dan Efeknya terhadap Nilai Perusahaan (Studi pada BUMN yang terdaftar di Bursa Efek Indonesia Priode 2012-2014). Jurnal Administrasi Bisnis, 33 (1): 146-153.

Ghozali, I, 2009. Teori Konsep dan Aplikasi dengan SPSS 17. Semarang: Badan Penerbit Universitas Diponegoro.

Gozali, N. 2012. Dampak Penerapan Prinsip-Prinsip Good Corporate Governance terhadap Kinerja Perusahaan. Skripsi. Fakultas Ekonomi Universitas Pembangunan Nasional Veteran Jawa Timur.

Hasmawati, 2014. Faktor-Faktor yang Mempengaruhi Penerapan Akuntansi Akrual pada Satuan Kerja Perangkat Daerah Pemerintah Daerah Kota Parepare. Skripsi. Fakultas Ekonomi UMPAR.

Hermanda, C. 2010. Penerapan Good Corporate Governance terhadap Kinerja Keuangan Perusahaan. Skripsi. Fakultas Ekonomi Veteran Jawa Timur. 
Jusup, A. 2011. Dasar-Dasar Akuntansi. Edisi Ketujuh. Yogyakarta: Sekolah Tinngi Ilmu Ekonomi YKPN.

Kasmir. 2014. Analisis Laporan Keuangan. Jakarta: Rajawali Pers.

Lastuti, A. 2002. Penerapan Prinsip Good Corporate Governance Sebagai Upaya Peningkatan Investasi Tidak Langsung (Indirect Investment). Laporan Penelitian Universitas Padjadjaran. Bandung.

Leo, J. 2013. Pengaruh Konsentrasi Kepemilikan, Ukuran Perusahaan, dan Mekanisme Good Corporate Governance terhadap Pengungkapan dalam Laporan Tahunan Studi Pada Perusahaan Manufaktur di BEI. Jurnal Ilmu dan Riset Akuntansi, 2 (1): 10-18.

Nizamullah, D. dan Syukriy. 2014. Pengaruh Penerapan Good Corporate Governance terhadap Kinerja Keuangan (Studi Empiris pada Perusahaan Perbankan yang Terdaftar di Bursa Efek Indonesia 2010-2012). Jurnal Akuntansi, 3 (2): $42-53$.

Nugroho, Y.A. 2011. Olah Data Dengan SPSS. Yogyakarta: PT Skripsi Media Creative.

Oktadella, D. 2011. Analisis Corporate Governance terhadap Integritas Laporan Keuangan. Skripsi. Fakultas Ekonomi Universitas Diponegoro Semarang.

Prasetyo, A. 2009. Corporate Governance. Fakultas Ekonomi UI.

Rahmawaty, D. 2015. Pengaruh Akuntabilitas Dan Transparansi Laporan Keuangan Daerah Terhadap Kualitas Laporan Keuangan Pemerintah Daerah Studi Kasus Pada Pemrrintahan Privinsi Jawa Barat. Skripsi. Universitas Widyatama.

Ristifani. 2009. Analisis Implementsi Prinsip-Prinsip Good Corporate Governance dan Hubungannya terhadap Kinerja PT Bank Rakyat Indonesia (Persero) Tbk. Skripsi. Fakultas Ekonomi Universitas Gunadarma.

Sapitri, R. 2010. Pengaruh Mekanisme Corporate Governance terhadap Ketepatan Waktu Pelaporan Keuangan. Skripsi. Fakultas Ekonomi Universitas Diponegoro Semarang.

Setyawan, A.A. 2016. Tata Kelola Badan Usaha Milik Negara (Penerapan Good Corporate Governance di Perum Damri Kantor Cabang Surabaya. Jurnal Kebijakan dan Manajemen Publik, 4 (2): 327-337.

Sudjana. 2000. Metode Penelitian Kuantitatif, Kualitatif dan $R \&$ D. Bandung: Alfabeta.

Aswadi, S.A.W. 2014. Pengaruh Akuntabilitas dan Transparansi terhadap Kualitas Laporan Keuangan (Studi Kasus pada Pemerintah Kab. Pinrang). Skripsi. Universitas Hasanuddin Makassar. 